Article

\title{
Rights in the Time of Populism: Land and Institutional Change Amid the Reemergence of Right-Wing Authoritarianism in Colombia
}

\author{
Sergio Coronado ${ }^{1,2,+(\mathbb{D})}$ \\ 1 Otto-Suhr-Institute of Political Science, Freie Universität-Berlin. Ihnestr. 22, 14195 Berlin, Germany; \\ sergio.coronado@fu-berlin.de \\ 2 Political Ecology Research Group, the International Institute of Social Studies, Kortenaerkade 12, \\ 2518 AX The Hague, The Netherlands \\ $\dagger$ Associated Researcher at Cinep/PPP, Bogotá Cra 5 No. 33B-02, Colombia.
}

Received: 19 June 2019; Accepted: 27 July 2019; Published: 31 July 2019

\begin{abstract}
In Colombia, right-wing leadership returned to power after winning the presidential elections in 2018 in a campaign in which they opposed the previous government, primarily because of the negotiations and peacemaking with the FARC-EP (Fuerzas Armadas Revolucionarias de Colombia-Ejército del Pueblo 'Armed Revolutionary Forces of Colombia-People's Army'), Colombia's largest guerrilla organization. Globally, there is a vibrant academic debate about how to characterize the current rise of right-wing populism or authoritarianism, but more profound insights from each country's situation and its political economy implications are needed. The victory in Colombia was due to numerous factors, including the support from some rural elites who have historically obstructed the enforcement of redistributive land policies. However, the populist aspirations of the right-wing government have been persistently frustrated not only by social unrest and political mobilization but also because of the enforcement of institutions previously incorporated into the country's political scenario. Specifically, in terms of agrarian political economy, two sets of human rights-oriented institutional changes are relevant regarding this matter: (a) the Land Restitution Law enacted in 2011 and (b) the Comprehensive Rural Reform contained in the Agrarian Chapter of the Peace Agreement between the national government and the FARC-EP in 2016. The purpose of this paper is to ground the ongoing theoretical and political debate about the rise of different forms of populism and right-wing authoritarianism in the current Colombian political context, and its implications on the countryside. The analytical contribution of this paper is twofold: On the one hand, I propose an alternative for explaining the nature of the current political regime in Colombia as right-wing authoritarianism; on the other hand, I analyze some features of such regimes in terms of its disputes with the enforcement of human rights-oriented institutions, that are in force as the result of political processes triggered by peasants' mobilization.
\end{abstract}

Keywords: authoritarianism; populism; institutional change; agrarian policies; human rights; land restitution; peace agreement; rural politics; Colombia

\section{Introduction}

The rise of different forms of populists and authoritarian political projects across the world is defying democratic systems and institutions while raising critical questions regarding the causes and implications of this political phenomenon in current times. Currently, there is a broad academic and political debate around how accurate it is to consider divergent and uneven political situations as "populist." In the political field, a broad range of actors-from traditional parties to social 
movements-have expressed their concern regarding the rise of populist projects, particularly right-winged, that are threatening democratic pillars and institutions, such as the separation of powers and multilateralism. For instance, on the one hand, during the European elections in 2019, there was an enormous concern among traditional political actors around how much support was likely to gain right-wing political parties such as 'Vox' in Spain or 'Alliance für Deutschland' in Germany. In January 2019, the German Chancellor Angela Merkel stated that "that the rise of right-wing populist parties in Europe was "a poison" and that nationalist policies risked fracturing international ties"1. In such a context, one of the key questions was around their capacity for undermining multilateral European Union institutions from within ${ }^{2}$. On the other hand, agrarian social movements as "La Via Campesina" have alerted about the risk of the rise of right-wing populism and its impacts on migrant and refugee policies and the violation of human and environmental rights of indigenous and peasants in countries under right-wing populist regimes as Bolsonaro's Brazil ${ }^{3}$.

In the academic field, different scholars have reflected and debated around the current political momentum. Drawing on early conceptualizations from scholars as Stuart Hall and Chantal Mouffe, academics have debated a trying to grasp an understanding of the current rise of populism. As a part of such a debate, Scoones et. al, considered some features of authoritarian populism for analyzing the linkages, roots, and contestation of such a phenomena in the rural world, including "the embrace of nationalism [ ... ]; highly contested national elections, resonant with broad-brush appeals to 'the people', in which candidates are rewarded for 'strong man' talk that pits insiders against outsiders of different colors, religions and origins; growing concern over the 'mobile poor', including refugees and migrants whose presence seems to threaten a shrinking resource base; appeals for security at the expense of civil liberties; a concerted push to increase extractive capitalism at all costs; and, finally, a radical undermining of the state's ability to support the full range of citizens, while utilizing state powers to increase surplus for a minority" ([1], p. 1). While some consider accurate to draw on Hall's concept of authoritarian populism, others argue that using such notion is a misunderstanding of Hall's original proposition, because it was coined for denoting the ideological consent around neoliberalism during the 1980s [2]. Furthermore, critical discussions have emerged, for instance, regarding the causes behind populisms' episodic character, whether such character relates to its ambivalent positions towards institutions, or its relationship with capitalism's cyclical crises, among other topics [3].

Although he uses of both the concept and its theoretical assumptions has been highly debated, the gravity and the fragility of the political momentum has not, as well as the urgency to deliver more in-depth analysis for understanding its entanglements and outcomes. Scholars have drawn on such debate for developing notions that are useful for analyzing each country's political momentum. Such concepts include 'authoritarian corpopulism', for highlighting the interconnections of agribusiness corporations with the state and the elites amid the rise of conservative politicians in Guatemala [4]; 'right-wing populism' for distinguish it as a "regressive, conservative or reactionary type of populism that promotes or defends capitalism in the name of the people; in its current manifestation, it is also xenophobic, nationalist, racist, and/or misogynistic" ([3], p. 3), or for stressing its particular appeal to the-white and Christian-people to engage against both elites acting from above and parasites from below in the current political scenario in the United States [5]. Therefore, although the notion of authoritarian populism is useful as an overarching concept for raising the attention of the current political momentum and some of its features beyond countries' borders, it also results clear that each

1 See: https://www.dw.com/en/germanys-angela-merkel-decries-right-wing-populism-as-poison-at-davos-summit/a42292865 (accessed on 19 July 2019).

2 For more insights about populism within the current European situation see: https:/www.nytimes.com/2019/05/19/ world/europe/european-parliament-elections-populists.html; and https://www.bloomberg.com/opinion/articles/2019-05-20/ european-parliament-elections-and-the-populist-threat-to-the-eu (accessed on 19 July 2019).

3 See: https://www.eurovia.org/ecvc-and-340-organizations-call-on-the-eu-to-immediatly-halt-trade-negotiations-withbrazil/ (accessed on 19 July 2019). 
regional and national political process challenges this notion, creating space for developing more precise concepts for guiding better the analysis.

Across regional contexts, populism is associated with multiple and even divergent meanings. However, it could be stated that, compared with previous periods, such a concept is currently charged with negative perceptions [6].

Two additional elements should be considered a political project as populist. On the one hand, populism is referring to a situation in which a government or a political project claims to represent the vast majorities of a countries' population. Such situation converges with the massive support of the electors to that political project [7]. On the other hand, populism is usually associated to a political scenario on which democratic institutions, namely the independence and autonomy of state branches, the guard of fundamental rights and liberties and the protection of political minorities through democratic channels, are threatened by the rise of a government that shows little respect to those principles arguing the need for overcoming crisis. In these situations, populism is usually conflated with authoritarianism, and the human rights international infrastructure becomes crucial for confronting them [8].

The insights of the debate mentioned above should not be considered as a check-list for identifying an authoritarian populist political project, but to identify relevant aspects for addressing the questions that need to be raised for grasping an understanding about how these projects are gaining support by different groups within a society, how progressive and democratic forces are confronting them, and what are its multiple relations with the rural world.

The purpose of this paper is to ground the ongoing theoretical and political debate about the rise of different forms of populism and right-wing authoritarianism in the current Colombian political context, and its implications on the countryside. The analysis of contemporary rural politics in Colombia is one of the best ways for grounding both political and theoretical debates. On the one hand, the presidential elections of 2018 gave the victory to the candidate appointed by the right-wing populist leader Álvaro Uribe, who counted with vigorous support from different regional rural elites. On the other hand, and partly because of the peace agreement signed between the national government and the FARC-EP (Fuerzas Armadas Revolucionarias de Colombia-Ejército del Pueblo 'Armed Revolutionary Forces of Colombia-People's Army'), the country is undergoing a transitional scenario on which the enforcement of reforms on land policies, that follows a human-rights approach, is one of the pillars of the peacebuilding process. For addressing the purpose of the paper, I will focus on the disputes between the enforcement of those reforms and the current right-wing government.

Substantial obstacles impede considering the current government in Colombia as right-wing populism. Despite meeting some of the criteria mentioned above, the notion of populism in the Latin American context is historically loaded. Populism was a widespread and contested concept within scholarship for analyzing the rise of charismatic leaderships that gained political power at for from the 1940s until 1960s in such region. Later, it was also used for considering a second wave of populists at the end of the 20th century, and more recently it has been used for labeling the left-wing 'pink-tide' governments [9]. After analyzing the scholar debate about this notion in Latin America, Wydeland defined a populism as: "an individual leader seeks or exercises government power based on support from large numbers of followers" ([7], p.12).

In the absence of both massive popular support, and of a solid multi-class nationalist alliance, the current Colombian government does not make a case as populist, particularly compared with the presidential mandate of the charismatic leader Álvaro Úribe (2002-2006 and 2006-2010). Therefore, in the absence of a better term, I consider the current political scenario in Colombia adjusts better to the concept of right-wing authoritarianism. Grounded in the tradition of the Frankfurt School, and following the pioneer work of Adorno and Horkheimer on this matter [10], authoritarianism and right-wing authoritarianism are terms widely used within psychology scholarship, mainly for studying preferences and behaviors of individuals regarding traditional values, authoritarian submission, and prejudices [11]. Moreover, the term has also been used for describing and analyzing political regimes. 
Altemeyer considers that the primary difference between right-wing and left-wing authoritarianism does not rely on the political orientation of a given regime (conservative or leftist) but instead depends on the kind of the authority that is followed by a constituency of citizens. Accordingly, the former occurs when those authorities represent the status quo of a society; meanwhile, the latter takes place when those authorities aim to overthrow the establishment [12]. Other characteristics of right-wing authoritarianism includes an excessive use of force and political repression as a means to deal with democratic challengers and opposition, exacerbation of nationalism, deprivation of civil liberties, and attempts to concentrate and centralize political power [13]. Besides those generic features, there are aspects of such a regime and its interaction with rural politics that will be explored in the analytical part of this paper.

For the analysis of the rural politics I consider peasants' agency, as a factor that has triggered human rights-oriented institutional changes regarding property rights. Peasants movements in Colombia could not be considered as a uniform social actor. Their demands have changed over time influenced by the dynamics of agrarian change, political violence, and the state-society relation. For this paper, I consider mainly the movements grouped in the coalition entitled "Cumbre Agraria, Campesina, Étnica y Popular." Such coalition reunites different members of La Via Campesina in Colombia, alongside with indigenous peoples', afro-descendant, and rural women organizations. Their central demands encompass the enforcement of redistributive land reform, the fulfillment of human and social rights for all rural dwellers, claims towards the recognition of the peasantry as a political actor, anti-extractivism, and the protection of different forms of territorial rights as a means for achieving higher levels of autonomy and self-determination [14]

In the time of populism, where different political projects that could be characterized as such are gaining terrain, or at least have the aspirations of becoming so, human rights-oriented institutions could play a critical role in terms of contention of their consolidation. By human rights-oriented institutions, I mean the result of the political processes through which existing institutions are adjusted and adapted, or new institutions are created for meeting human rights protection and realization standards allocated within a human rights instruments, and frameworks developed both the international and the national levels. In some cases, such processes include social movements' strategies for creating human rights at the global scale [15] and their efforts for extending their implementation to the national level through various means: judicial claims, legislative advocacy and several protests' repertoires, as different peasants' movements have done with claims over the fulfillment of the right to food, and subsequently demanding access and effective control over rural lands [16].

A human rights approach in terms of democratic land access and control implies that state actors must engage with "respecting and protecting existing democratic access to land where it exists, promoting redistribution of access to land where it is required, and restoring lost land access and control where it is demanded, correspond to the state's three core human rights obligations (respect, protect, and fulfill)" ([17], p. 68).

Although they have experienced a protracted and profound process of institutionalization, human rights must not be understood in apolitical or ahistorical ways because they are the result of different sort of social movements demands (including civil rights, workers, women, and environmental). Despite its institutionalization, claims for their respect, protect, and fulfill by social movements usually encompass demands for social justice. Despite its inclusion in national or international legal frameworks, human rights and human rights oriented agrarian institutions are neither self-interpreted nor self-implemented [18]. Social movements efforts towards human rights fulfilment are usually counter-hegemonic [19], and therefore are a decisive tool for confronting populist and authoritarian regimes.

This paper is mainly based on my PhD research about rural politics, peasant agency and institutional change in the context of convergent transitions in the Colombian countryside. For this paper, I am focusing on two reforms informing institutional change on property rights over rural lands: Land Restitution Law and Comprehensive Rural Reform — contained in the Agrarian Chapter of the 
Peace Agreement. Those reforms are relevant in at least two ways for this paper: they are crucial in terms of how the reemergence of right-wing authoritarianism is being contested, and they are the result of political processes on which peasants' agency played a pivotal role. Methodologically, I developed a detailed observation and reconstruction of the political processes that gave birth to those reforms within the period 2010-2019. Such reconstruction is based on different sources: press articles, policy papers, public hearings, grey literature, legal documents, and judiciary rulings. The data collection took place from December 2018 to July 2019. The analytical contribution of this paper is twofold: one the one hand I propose an alternative for explaining the nature of the current political regime in Colombia as right-wing authoritarianism; on the other hand, I analyze some features of such a regime in terms of its disputes with the enforcement of human rights-oriented institutions, that are in force as the result of political processes triggered by peasants' mobilization.

After this theoretical introduction, I will offer some key elements of the national context of Colombia for understanding the interaction between human rights, rural politics, and authoritarianism, alongside with complementary theoretical insights. Subsequently, I will describe the political processes that gave birth to such reforms. Afterwards, I will survey key features of the right-wing authoritarian government and its efforts for eroding the human rights inspired institutional setting, as much as its political economy implications. Finally, I will reflect on the paths and risks in terms of building alternatives to the consolidation of authoritarian projects.

\section{Human Rights, Rural Politics and Right-wing Authoritarianism in Contemporary Colombia}

As mentioned before, populism is a familiar notion in the Latin American political scholarship. After the first wave of populists' governments of the 1940s and 1950s, the region experienced a second period of charismatic leaders, usually known as 'neopopulists' as Fujimori in Perú and Uribe in Colombia. In the 1990s and the 2000s, both presidents challenged the democratic setting of each country and succeeded in prolonging their mandates beyond what each country's constitutional framework permitted. Both leaders counted on substantial support by electoral majorities, both enforced fierce neoliberal reforms, and both left office amid strong accusations of being responsible for massive human rights violations amid each one's crusade against terrorism. However, human rights institutions played a crucial role in curbing their aspirations. In 2010, the Constitutional Court prevented Uribe's attempt for running for a third presidential election, while in Perú after his resignation in 2000, Fujimori faced a protracted criminal trial around human rights violations charges and he was convicted and sentenced to 25 years in prison. As in the cases of Fujimori and Uribe, there is an opposition between human rights institutions and authoritarian or populist political projects, mainly because human rights usually entail adequate limitations and inhibitions to the exercise of power. For instance, on the one hand, in 2019 the right-wing governments of Brazil, Colombia, Argentina, Chile, and Paraguay delivered a statement demanding reforms within the Inter American Human Rights System, specifically in terms of limiting the extent to which the jurisprudence of the Court influences rulings over other cases and to limit the capacity of the International Entities to conduct subsidiary investigations regarding human rights violations ${ }^{4}$. On the other hand, the left-wing populist president of Venezuela, Nicolás Maduro, denounced the "San José Agreement" and by doing so the Inter American Human Rights Court lost competence for addressing and ruling over human rights violations cases in this country ${ }^{5}$. Although some claims made by authoritarian or populist heads of government regarding the role of multilateral human rights institutions could resonate with some of the questions raised by scholars within critical approaches as Marxism [20] or decolonial [21] theory; it is also true that social movements, including

4 The official statement is available at: http://www2.mre.gov.py/index.php/noticias-de-embajadas-y-consulados/gobiernosde-argentina-brasil-chile-colombia-y-paraguay-se-manifiestan-sobre-el-sistema-interamericano-de-derechos-humanos? ccm_paging_p=4 (accessed on 20 July 2019).

5 See:https://www.bbc.com/mundo/noticias/2013/09/130909_venezuela_corte_interamericana_salida_derechos_humanos_ az (accessed on 20 July 2019). 
those working for agrarian justice, have also use human rights framework and institutions for framing their struggles [16].

Besides being relevant within criminal cases against neopopulists, human rights instruments are also crucial for placing institutional changes and adjusting policymaking at several levels. In Colombia, since the promulgation of the 1991 Constitution and its corresponding incorporation of a broad and ambitious bill of rights, multiple formal institutions and policies have adapted to meet human rights approaches. Some of these changes have taken place because of the development of the human-rights jurisprudence by the Constitutional Court, while others have taken place at Congress. As a result, a considerable amount of land and related agrarian policies are following a human rights approach. For instance, on the one hand, the Constitution and the jurisprudence of the Constitutional Court have recognized territorial rights to indigenous and rural afro-descendant communities in Colombia, and in many cases the protection of such rights have imposed effective limitations to state and private actors, arguably blocking land commodification processes over those lands on which agrarian reform entities and judges have entitled land and rights on behalf of these populations. On the other hand, agrarian social movements have used human rights frames and institutions for contesting market-oriented agrarian policies such as the 2007 Rural Development Statute. Such a legal framework was declared unconstitutional because of the violation of ethnics' groups to prior, free, and informed consent rights regarding the enactment of such legislation [22]. Nevertheless, such processes do not occur automatically. Instead, they are triggered by peasants' movements, human rights defenders, and other groups using their political agency.

I argue that some legal reforms introduced during the 2010s and the jurisprudence of the Constitutional Court have introduced significant changes in the institutions of property rights over rural lands in Colombia, undermining the dominant neoliberal approach introduced since the late 1980s and the early 1990s. The 1994 Agrarian Reform Law consolidated the shift towards the market-assisted agrarian reform, previously incorporated in the legal landscape in 1988. Since then, efficiency became the main criteria for granting and allocating land rights in the countryside, swapping out the redistributive approach that marked previous efforts of state-led agrarian reform. Under such schema, the allocation of property rights over rural lands is usually limited to formalization programs, on which peasants or small-scale producers obtain a land title of the plot they are already farming, regardless of subjective capacities for farming and objective inadequacy of the land plot for meeting the needs of the household; such programs could be considered as "formalization in lieu of and/or without redistribution" ([17], p. 68). Conversely, the legal reforms and the jurisprudence of the Constitutional Court arguably have undermined efficiency as the criteria for allocating property rights in Colombia. Two legal reforms have brought back into the institutional setting restitution and redistribution approaches as alternative criteria for granting property rights over rural lands: the 2011 Land Restitution Law and the Comprehensive Rural Reform. To different extents, both frameworks are the result of social movements' demands, and both are influenced by human rights international instruments and frameworks.

In Colombia, the right returned to power after winning the presidential elections of 2018 in a campaign during which they opposed the previous government, primarily because of the negotiation and peacemaking with the FARC-EP. Ivan Duque, the candidate of the Centro Democrático's party won the election in the ballotage with $54 \%$ of the votes. His victory responded to numerous factors, including the support from some rural elites who have historically obstructed the enforcement of redistributive land policies. In Colombia, regional rural elites could not be assumed as a homogeneous or indistinct mass. Conversely, those groups are regionally differentiated and have diverse interests regarding the state and the structures of political and economic power. In this paper, I use the notion of rural elites for addressing a specific type of these social actors that could be founded in several regions of Colombia, particularly in those incorporated within the country's agrarian border before the 1950s, namely areas on which the settlement process was relatively stagnant at that period. Those rural elites reached their dominant position by taking control over several aspects of the economic and political apparatus in 
their regions. For instance, in Córdoba—a department located in the Caribbean region-the political and economic power of those elites was enlarged because of the integration of emergent political and economic forces based on cattle-ranching, commercial agriculture, and market [23]. One distinctive characteristic of these regional elites is that their political and economic power mainly depends on their capacity to concentrate property rights over rural lands. Historically, those rural elites played a critical role in terms of blocking previous attempts for delivering redistributive agrarian reform. In 1973, an alliance of rice-growers and cattle-ranchers promoted a legislative amend that effectively blocked the enforcement of the 1961 and 1968 agrarian reforms laws [24]. Currently, the unions of cattle-ranchers and oil-palmers are one of the sectors that have manifested their opposition to the enforcement of the land restitution law and the Comprehensive Rural Reform, I will further develop such an argument.

Despite being driven by former president Uribe, a popular leader, Centro Democrático's government could not be entirely considered as populist, mainly because of the lack of massive popular support. Compared with the electoral results achieved by Uribe presidential campaigns in the 2000s, president Duque lacks popularity, as proved by different surveys ${ }^{6}$. Furthermore, the strong opposition of various political actors impedes him to count with the majorities in Congress, while the High Courts have proved their independence by ruling contrarily to government aspirations ${ }^{7}$. Notwithstanding the lack of popular support, Duque's government is increasingly turning authoritarian, among multiple reasons, by not-enforcing key parts of the agreements signed with the FARC-EP, and by rolling-back the enforcement of the human rights-oriented institutions in the agrarian field enumerated above.

\section{Human Rights-oriented Institutional Change in the Agrarian Field}

Colombia is an exceptional case for analyzing the tensions between the rise of political populists or authoritarian political projects, the enforcement of human rights-oriented institutions and its implications in the countryside. Compared with other countries of the region, Colombia counts with relatively stable political institutions: presidential and legislative elections are carried out every four years, diverse political groups participate in such elections and, even in some cases alternative forces have gained regional elections. Despite efforts towards peacebuilding violence continues to be an overarching element of the Colombian political system. Besides the peace agreement signed in 2016 with the FARC-EP, the Colombian government facilitated the demobilization of paramilitary groups in the mid-2000s and during the late 1980s and early 1990s developed peace negotiation with other leftist insurgencies. The Constitution of 1991 is a landmark in this regard, not only because of the significant participation of non-bipartisan political forces, including former guerrilla leaders, and indigenous peoples' representatives; but also, because of the inclusion of a comprehensive bill of rights. However, the human rights-centered institutional framework has had little impact in terms of land access and redistribution. Attempts for enforcing redistributive land reforms were frustrated by some rural landowning elites during the second half of the 20th century, while the market-led

6 In February 2019, amid a verbal confrontation with Venezuela's president Nicolás Maduro and after a terrorist attack perpetrated by the Ejército de Liberación Nacional-ELN, President Duque's popularity reached the highest point with 42,7\% See: https://www.eltiempo.com/politica/gobierno/imagen-del-presidente-ivan-duque-en-febrero-encuesta-invamer-327284 (accessed on 20 July 2019). However, such a situation turned unendurable, according to the most recent YanHaas poll, in June 2019 President Duque's approval dropped down to $28 \%$, while $68 \%$ of the population disapproves his performance. See: https://www.elespectador.com/noticias/politica/63-de-los-colombianos-desaprueban-la-gestion-del-presidente-duquesegun-encuesta-yanhaas-articulo-866957 (accessed on 20 July 2019).

7 During his first year of government, President Duque attempted to modify the Special Jurisdiction for Peace (Justicia Especial para la Paz-JEP, the transitional justice system agreed with the FARC-EP as a pillar of the peace accord), by objecting the statutory law enacted by the Congress. According to the constitutional procedure, the Congress must consider the presidential objections and vote over them and remit them again the Constitutional Court for its final constitutional examination. Neither the Congress nor the Court endorsed the presidential objections and after a long political and legal debate, the President enacted the original version of the statutory law. For a detailed analysis on this matter see: https://www.dejusticia.org/ litigation/los-argumentos-sobre-las-objeciones-presidenciales-que-presento-rodrigo-uprimny-ante-el-congreso/ (accessed on 20 July 2019) 
agrarian reform of 1994 has failed in terms of securing access to credit to poor peasants, and avoiding land prices' distortions [25]. The concentration of rural lands numbered with a Gini index of 0.88 [26], and such inequality fuels rural violence in multiple ways. Efforts towards rural democratization and peacebuilding enabled the environment for the development of two significant institutional changes in the agrarian field during the 2010s, and such transitions are also attempting to overcome a well-founded anti-peasant bias in agrarian policymaking.

In Colombia, formal agrarian institutions have historically favored the interests of rural land owning elites by enabling and legalizing the process of land concentration, leading towards a higher concentration of wealth and political power on their behalf [27]. Since the late 1980s and during the 1990s, rural policies experienced a neoliberal shift, and consequently, the agrarian law introduced a market-oriented land reform paradigm, fostering a 'conservative modernization' of the agricultural production. Although the privileges of large-scale landowners remained unaltered, the new policy largely favored agribusiness, by prioritizing public support to large-scale investors in terms of facilitating their access to land, resources, and credit while threatening livelihoods of small-scale farmers and peasants $[24,28,29]$.

Besides the neoliberal shift on agrarian policies, other kinds of changes within this institutional setting have also taken place, especially after the promulgation of the Constitution of 1991. Such institutional changes are driven by social actors struggling for alternatives on agricultural and land policies, particularly in terms of demanding more democratic land distribution and the promotion of alternative rural development models, besides large-scale agribusiness or cattle-ranching. Furthermore, such transitions within the institutional framework are also boosting alternatives to agro-extractivism and natural resources exploitation.

By institutional change, I mean relative stable shifts on the rules and procedures that structure the interaction between social actors and with the state [30-32]. The sources of institutional change vary from one context to others, but in this case, there are at least two relevant variables for analyzing how these transformations are taking place. In the first place, substantial changes in the political context may imply a shift of strategies within existing institutions. The new Constitution in 1991 delivered an important process of democratization of the Colombian society. The new framework reinvigorated the independence of the branches of the state, and the creation of the Constitutional Court and other human rights entities encouraged the dissemination of human-rights instruments and approaches by social and state actors. Within such a new constitutional framework, groups traditionally underrepresented in the state structures found in the judiciary an opportunity for pursuing their demands. Specifically, in the agrarian field, different studies demonstrate how peasant movements have channeled some demands through legal and judiciary mechanisms, triggering institutional change [33,34]. Furthermore, institutional change takes place when "political actors adjust their strategies to accommodate changes in the institutions themselves" ([30], p. 17); besides the opportunities brought by the broad political transition in the early 1990s, different actors struggled to accommodate changes within the institutional agrarian setting. The approval of the land restitution policy by Congress in 2011 is arguably one of the changes illustrating such a situation. However, it is substantial to keep in mind that pieces of legislation are not institutions themselves. The articulation and enforcement of the legal reforms analyzed in this paper are indicating a broader process of institutional change regarding property rights over rural lands, through which efficiency is challenged as the criteria for defining land rights allocation and granting.

One distinctive characteristic, if not the most important, of this kind of change is the progressive incorporation of human rights instruments and approaches into the transformed institutions. The relevance of the human rights approach relies on the fact that it facilitates the articulation of institutional change with the social mobilization claiming democratic access and control over land and other natural resources. In this sense, the transformation of agrarian institutions is articulated with broader agrarian justice goals, such as the enforcement of land policies with a clear bias favoring the rural poor, the protection of existing land rights and the enforcement of redistributive land policies [17]. 
Those features are at the core of the dispute between the right-wing authoritarian government and social actors pushing forward the impacts of institutional change, and these disputes also could be translated into a political economy perspective, as much as these changes facilitate shifts on the access and control over land and natural resources from powerful to powerless actors. Subsequently, I will explore two reforms informing institutional changes on property rights over rural lands in Colombia: (a) the reform of the agrarian legal framework carried out by the approval of the land restitution law in 2011 and (b) the reforms included in the Agrarian Chapter of the 2016 peace agreement between the national government and the FARC-EP.

\subsection{Legal Reforms: Land Restitution}

How was the land restitution policy possible in a political context habitually closed for approving reforms favoring the rights of dispossessed peasants? It is commonly assumed that the approval of this policy responded mainly to the alliance between former president Santos with the Liberal Party and, especially as a result of his commitment to making such reform possible. Quoting his own words: "If this law is passed, being President has been worthwhile" 8 . Nevertheless, it is also necessary to consider other crucial elements, usually blurred in the official narrative.

Before such presidential backing, human rights defenders and victims' movements engaged in attempts for creating a land restitution legal framework. After the demobilization of paramilitary groups facilitated by the "Justice and Peace Law" enacted in 2005, human rights defenders and social movements advocates insisted on the necessity of developing a complementary framework for guaranteeing victims' rights, particularly for those affected by forced displacement and land dispossession. From 2006 until 2010, at least two attempts for having a statute for victims' rights and land restitution were frustrated by the majorities in Congress controlled by Uribe's government [36]. Those attempts were steered by victims' movements, peasants' movements and human rights defenders. They raised questions about the concept of restitution, what to restitute and how to do it, enabling the approval of the law at the Congress in 2011 [37].

Therefore, the window of opportunity opened by president Santos hinged on previous attempts from social actors for making such legal reform. The land restitution policy faced, and still faces, the challenge of redressing the number of victims estimated at 6 million and restituting property rights over an area calculated between 4 and 8 million hectares of land [38]. The legislative debate that took place between 2010 and 2011 relied on the leadership of Santos' government, and as a result, they convinced skeptical political actors that previously opposed to the approval of such reform, while other actors expressed their opposition to such legal framework, especially former president Uribe.

The legal framework consists of the Law 1448 of 2011 and two Legislative Decrees regulating independent procedures for the restitution and reparation of indigenous and Afro-descendant victims, the decrees 4633 and 4635 of 2011 respectively. These special decrees were also the result of ethnic groups' claims for expecting special procedures for the protection of their rights and were grounded on the Constitutional Court's jurisprudence on Free, Prior and Informed Consent-FPIC. The process for obtaining the FPIC from the indigenous groups for the approval of this special decree is considered as an outstanding example of how such endeavors could be carried out, and ended with innovative formulas proposed by indigenous peoples' representatives such as the recognition of land and territory themselves as victims of the armed conflict [39].

However, the design of the land restitution law was not freed from the influences from rural landowning elites who would be affected by its enforcement. Key land restitution provisions have proved their limits for bringing power balance in existing asymmetrical relations. Moreover, the policy has proved limitations in transforming the structures of rural land concentration in the Colombian countryside. Such limits are explained at least at two levels. At the lawmaking level, the legal

8 Own translation from the original quote in Spanish: "Si se aprueba esta ley habrá valido la pena ser presidente." [35] n.p. 
framework included clauses for protecting the interests of some rural elites who may have benefited from massive land dispossession and who had strong representation in Congress [40]. At the enforcement level, the land restitution policy has faced enormous challenges in terms of affecting large-scale landowners, agribusiness, or extractive industries [41,42]. However, the inclusion of those safeguards was insufficient for convincing the detractors of such an initiative, and both the enactment and the enforcement of the land restitution policy rapidly became the sticking point between the new opposition led by former president Uribe. I will be back to such tension afterward.

Although explaining the implementation of land restitution policy exceeds the goal of this paper, it is worth mentioning that despite the contradictions mentioned above, the land restitution law is still a landmark in the agrarian field in Colombia. During the first years, the land restitution judges ruled in favor of the protection of territorial rights of indigenous communities affected by mining concessions, in other cases, historical demands for the formalization of land rights of victims of forced displacement where finally solved thanks to the intervention of the new state actors created by the legal framework [43]. However, it is insufficient for attending to the structural problems of the Colombian countryside, particularly in terms of promoting a more democratic distribution of land among the rural population.

The agrarian chapter of the peace agreement signed between the FARC-EP and the Colombian government arguably addresses such problem more integrally. Furthermore, the prolongation of the enforcement of land restitution policy is fully articulated and supported in the context of the enforcement of the peace agreement. I will now provide a better understanding of the implications of the agrarian chapter of the peace agreement.

\subsection{Agrarian Institutions for Peacebuilding: Comprehensive Rural Reform}

The peace agreement signed between the national government and the FARC-EP aims to exclude violence as an overarching element of the Colombian political and economic systems. In Colombia, the regimes of political and economic exclusion are supported by institutional and para-institutional uses of violence; actors excluded from the political and economic system often draw upon violence as a reaction to their situation; violence is used by the elite classes to impose particular development models [44]; and at the regional level, violence is also an expression of the uneven state-building process [45].

The protracted 53-years-old armed conflict is an expression of such overarching violence, although it has been recently transformed because of recent peace negotiations between the national government and the FARC-EP. Scholars from different stands agree that the agrarian problem is one of the core causes and structural factors explaining not only the ignition but also the evolution, of the internal armed conflict in Colombia [46-48]. Specifically, the FARC-EP found their territorial expansion and founded social bases in areas of relatively recent border expansion, on which peasants expelled from other regions more integrated to the agrarian markets, found shelter and protection from the economic and social squeeze through their engagement, in some cases, as coca growers [49,50]. More recently, the forced displacement and land dispossession executed mainly but not only by paramilitary forces, or as a consequence of their territorial control in given regions, also had transformed the Colombian countryside, favoring political and economic sectors that supported such illegal armies [42].

Despite such consensus, there are divergent and multiple explanations about the interaction between the emergence and evolution of the armed conflict with the dynamics of the various dimensions of the agrarian problem. While some explanations put more emphasis on land distribution and inequality, arguing that such factor triggered and fueled armed insurgency in the countryside [46]; others place more emphasis on the fact that illegal armies fostered landed property accumulation as a 
safeguard of the illegal rents obtained through violent means and that also is an indicator of the state incapacity to control illegal armed actors controlling drug-trafficking [51] ${ }^{9}$.

Overall, there are four aspects that explain the complex interactions between the emergence and evolution of the armed conflict and the agrarian problem. First, different kinds of unsolved land claims and demands were channeled through violence. Since its foundation in 1964, the former FARC-EP guerrilla demanded the enforcement of profound agrarian reform, through which large-scale land properties should be redistributed among poor landless peasants or peasants that do not have access to land to secure their livelihoods ${ }^{10}$. Secondly, the permanent expulsion of peasants from lands within the agrarian frontier was crucial for the constitution and consolidation of guerrillas in border expansion regions [53]. Thirdly, land purchasing and accumulation was used as a saving-fund for the investment of the profits derived from illegal economies, particularly drug-trafficking since the decade of the 1980s [54]. Such a process is an expression of "the co-optation of the paramilitaries forces by the narco-bourgeoisie in the late 1990s. This allowed it to negotiate its incorporation into the political elite and redefine its relationship with the state" ([55], p. 415). Fourthly, and linked with the previous statement, a massive phenomenon of forced displacement and land dispossession occurred during the intensification of the armed conflict. This lead toward a new process of land concentration favoring the interests of large-scale landowners, agribusiness investors and cattle-ranchers and affected different rural dwellers, mainly poor peasants. In the middle of the 1980s, the armed conflict experienced a period of intensification of actions against civilian population. From 1988 to 1995, 7.5\% of the total of the peasant population was expelled from rural areas [56]. Therefore, violent and forced displacement is one of the most prominent characteristics of the late stage of capital accumulation in Colombia. Forced migration facilitated land grabbing, and this was accompanied by a "process of broaden and deepening the capitalist 'market-imperative' in the agrarian sector" ([44], p. 329).

Besides of the rooted linkages between unsolved agrarian problems and the armed confrontation, the evolution of the violence in Colombia shaped the performance of agrarian institutions and triggered new cycles of land concentration. Law and legal institutions played different roles regarding each of the previous interactions between the agrarian problem and the armed conflict in Colombia. In different regional settings, notaries, governmental officials and public authorities legalized land dispossession wielded by armed groups, notably paramilitaries, by issuing land titles ignoring the legal frameworks protecting peasants' tenure rights $[57,58]$.

Therefore, although many of the land conflicts implicating poor peasants' claims over land rights are linked with the long-standing land concentration process; currently, such disputes are also shaped and triggered in relation with the most recent dynamics of the armed confrontation. The peace accord signed between the FARC-EP and the National Government took into consideration, not only the rooted agrarian origins of the armed confrontation, but also the different trajectories of interaction between the agrarian problem and the violence, particularly the land dispossession suffered by poor peasants during the last periods of the armed conflict. Hence, this accord aims to attend the causes of the armed confrontation to settle the basis for the construction of a durable peace with social justice [59].

The first part of the peace accord comprehends an ambitious program to transform the Colombian rurality named "Comprehensive Rural Reform." This new framework allocates transformations within

9 Although the latest dynamics of narco-traffic are relevant to understand the most recent evolution of Colombian armed conflict and its interaction with the agrarian problem since the middle 1980s, it results insufficient for providing a comprehensive explanation on the origin of rural insurgencies, dated at least 20 years before the incursion of narco-traffic in the dynamics of the armed conflict. Therefore, the interaction between the armed conflict and agrarian problem, including land concentration, rural poverty and the presence of illicit crops also depends on distinct periods of the evolution the dynamics of the armed conflict, the logic of territorial control deployed by armed actors and the degree of engagement with illicit economies [52].

10 In 1964, year of the foundation of the FARC-EP guerrilla, they launched their "Programa Agrario"-Agrarian Program. The program is one of the foundational statements for understanding their position regarding the agrarian problem and the underlying motivations of the armed unrest. The program was ratified and updated in 1993. See: https: //www.farc-ep.co/octava-conferencia/programa-agrario-de-los-guerrilleros-de-las-farc-ep.html (accessed on 28 February 2019). 
the agrarian institutions for addressing the underlying agrarian causes of the armed confrontation related to rural poverty, including land concentration, among other issues. Such transformation is intended to be carried out in three overarching ranges. The first refers to land formalization and redistribution. The goal is to formalize, secure, and protect land rights, estimated at 7 million hectares, to different kind of rural dwellers, focusing on poor peasants, but without excluding large-scale landowners. Complementary, the agreement aims to distribute without price, through the constitution of a "land fund," of 3 million hectares to landless peasants or to peasants that do not count with enough land to generate a livelihood. This part also includes a highly ambitious program to update land management institutions through the construction of a modern rural cadaster. The second part refers to the implementation of programs of territorial development ${ }^{11}$. The third part includes national scope policies to reinforce the transformation and modernization of the countryside ${ }^{12}$. Overall, one of the goals of the agreement is to transform a "anti-peasant" bias of rural and agrarian policies enforced by the Colombian State.

Secondly, the peace accord includes high-reaching policies regarding the transformation of the approach to combat illicit crops, drug production, consumption, and narco-trafficking. Concerning the impacts of such change in the countryside, it is worth to mention that the accord includes transitional policies to promote the substitution of illicit crops and the promotion of new economic activities for the population engaged with illegal crops. Regarding land policies, it is expected that the replacement of illegal crops will be accompanied with the formalization of land titles to peasants involved with the transition into licit production; and that granting formal rights should encourage poor peasants to abandon illicit activities. Although similar initiatives have been enforced in Colombia for more than two decades, this is the first time that a substitution program counts with the support of FARC-EP, and this could make an enormous difference concerning previous programs [60].

The extent to which the implementation of the peace agreement would transform the current agrarian structure and inhibit the emergence of new cycles of land grabbing is still unclear. However, different actors expect significant benefits from the implementation of the agreement and the decrease of violence in the countryside, particularly a capitalist expansion in expected because of the peace agreement' enforcement ${ }^{13}$. As mentioned before, one of the consequences of more than fifty years of armed confrontation is that land remained concentrated because of the violence exerted against rural dwellers. The armed conflict impacted and facilitated more land concentration in the already unequal agrarian structure in Colombia. The institutions regulating land rights have changed as a consequence of the land dispossession that took place during the armed conflict, particularly during the years of most intensive victimization against the civilian population [58].

The enforcement of the peace agreement is by far the critical sticking point between the right-wing authoritarian government and their counterparts. Since their victory in the 2016 peace referendum,

11 The goal of this programs is to focus State intervention in regions particularly affected by the armed confrontation with the enforcement of development programs orientated towards the reconstruction of the productive forces and the revitalization of the political life in given areas.

12 These policies comprehend the construction of rural infrastructure-roads, irrigation districts, housing and, electrification; infrastructure for rural education (schools and high education centers), mechanisms to foster peasant's access to credit and rural banking, technical assistance for production and commercialization, and even the formalization of rural labor, among other initiatives.

13 Multiple economic actors expect that agriculture production will grow in the years following the signature of the peace agreement between the government and FARC-EP. Agricultural grow is expected to take place as the result of the enforcement of the Comprehensive Rural Reform. According to the National Planning Department, during the years following the peace agreement the agriculture is expected to grow over $1.2 \%$ to $1.4 \%$ in addition to the regular growth rate [61]. The implementation of the peace agreement should lead agriculture to grow and the improvement of the conditions for farming, consequently land formalization and (re)distribution policies play a critical role in the accomplishment of such a goal. However, it remains unclear the extent to which such enforcement will prioritize rural working classes. The first decree enacted by the Government (Decreto 902 de 2017) for commencing the Comprehensive Rural Reform has been highly criticized because it could entail the enforcement of land formalization policies without consideration of class differences in the countryside, by granting property rights over public lands to all kind of rural actors, including large-scale owners and corporations [62]. 
they insisted in the necessity of limiting the extent of the Comprehensive Rural Reform included in the agrarian part of the peace agreement. Therefore, under the new government, the enforcement of the accord is highly questioned. One element to consider in this regard are the mobilizations from peasantry demanding the peace agreement's implementation. In different regions of the country, peasants have mobilized demanding the enforcement of specific agreements, particularly those around the implementation of illegal crop substitution programs. Such mobilization is taking place in an ongoing scenario towards the expansion of the Constitutional and human rights framework in Colombia while challenging the right-wing authoritarian government.

\section{Right-wing Authoritarianism and Its Disputes with Human-rights Oriented Institutions}

As mentioned before, there is a robust debate around how to characterize the rise of multiple and uneven political projects that are challenging institutional settings of contemporary democracies. Despite the pertinence of this debate, characterizing the political momentum in Colombia became a significant analytical challenge. On the one hand, the current Colombian government headed by the Centro Democrático's party commanded by former president Uribe is encouraged by the rise of authoritarian populists in other countries of the Americas, as Bolsonaro in Brazil or Trump in the United States. Their shared position on crucial topics such as the Venezuelan crisis, the reform on the Inter-American Human Rights System, and their repressive approach criminalizing narcotics consumption as an effective way to hamper narco-traffick, permit to consider the idea of a coordinated action of a regional axis of authoritarian populists [63]. Therefore, the current Colombian government needs to be analyzed in a relation of the regional context on which authoritarian populists have gained control over several countries' governments by electoral means.

On the other hand, considering this government as populist conveys a contradiction in terms, because of several factors already explained. However, those before-mentioned populist frustrations do not prevent this government from being considered as a case of right-wing authoritarianism. Onwards, I will survey some of the particular characteristics of the current right-wing authoritarianism in Colombia as follows, while analyzing key aspects of the disputes with institutional changes in the agrarian field described above.

\section{- Dependent on an iron-fist figure}

The current rise of the right-wing authoritarianism is explained by the protracted acceptation of Álvaro Uribe. The Centro Democrático party was founded as a pole of opposition to president Santos government, and particularly for hampering the ongoing peace negotiations with the FARC-EP guerrilla by competing in the legislative and presidential elections of 2014. Even though the name of the party recalls the affiliation to the political center, its statutes' covers critical characteristics of a conservative-populist movement. The party is well-founded on the charismatic figure of their leader. The members of the party must adhere to the work and ideas of former president Uribe, while the general statute grants him exclusive rights, including the right to be elected without restrictions at any party's committee, and the life right to preside the national convention and the national board of the party $^{14}$.

The victory of this party in the presidential election of 2018 is highly explained because of how former president Uribe capitalized the opposition against Santos and particularly against the peace agreement with FARC-EP. In 2016, an editorial of the New York Times appointed Uribe as "The man blocking peace in Colombia"15. Even though the parts founded alternatives for overcoming such blocking after the defeat the peace-plebiscite in October of that year, such election facilitated the

14 More information about the statutes of this political party and its ideology is available at www.centrodemocratico.com (accessed on 20 July 2019).

15 See: https://www.nytimes.com/2016/10/14/opinion/the-man-blocking-peace-in-colombia.html (accessed on 20 July 2019). 
re-accommodation of many political forces under the Uribe's leadership, including some regional rural elites, ultra-conservative religious groups, politicians formerly indicted for their linkages with paramilitary groups, among other sectors. Such an alliance that also counted with the support of the Conservative Party after the inclusion of their candidate as the vice-presidential formula gained victory after a highly-contested election.

- Combination of violence with formal respect to democratic institutions

One distinctive characteristic of the Colombian political regime is the paradoxical coexistence of a relatively stable and competitive democratic system with high levels of violence and political repression. Despite respecting the forms, institutions, and procedures governing the constitutional democracy; the political system permitted in different degrees the privatization of security provision with plausible effect in terms of widespread violence. Such a phenomenon has taken place in particular periods, especially during the intensification of the armed conflict against civilians, primarily rural population, from the middle 1990s until the end of the 2010s [64].

After the signature of the peace agreement with the FARC-EP guerrilla, the violence against grassroots' activists and social leaders and ex FARC-EP combatants have increased [65]. Although such violence is not a new phenomenon, currently human rights defenders are dealing with risks wrought under the new peacebuilding setup, especially in those regions on which its enforcement would entail deep transformations. For instance, the risk is higher on areas on which the reincorporation of former combatants into the democratic system dovetails challenges regarding shifts of peasant economies highly dependent on coca production and retailing. As mentioned before, the agreement included programs for facilitating the transition towards the legality of coca producers by transforming the repressive/criminal approach for human rights-oriented policy. Such institutional change hinged upon the prohibition of aerial aspersion with glyphosate ruled by the Constitutional Court in 2017. Conversely, Duque's government requested the Court, in a public hearing held in Bogota in March 2019, to contradict their jurisprudence by allowing once more the use of this herbicide as a mean to control the expansion of coca crops, opposing what was agreed on the peace accord ${ }^{16}$. The formal request of the government to the Judiciary authority matched the escalation of political violence amid protests in coca-producing regions, fueled by the lack of fulfillment of the government of the agreements signed with peasants' movements and build-up from the peace accord [66].

- Disdain towards human rights frameworks and institutions

The Constitution of 1991 marked a landmark in terms of human rights promotion in Colombia. The inclusion of a broader and more ambitious bill of rights, the creation of new state actors -such as the Constitutional Court-, and new mechanisms for enhancing human rights' protection, such as the writ for the protection of fundamental rights (Acción de Tutela), enabled the environment for a new period of engagement of landless peasants and rural workers with legal means, that resulted more advantageous compared with the former constitutional framework. In some cases, the human rights framework has imposed limits on the power of dominant actors while protecting the interests of the rural poor through legal contention strategies $[67,68]$.

While social movements attempt to expand human rights instruments by including new rights and interpretations, right-wing authoritarianism engages in disputes against human rights institutions and defenders. Populists and authoritarian actors often consider that there are too much liberty and rights, and that is partly the explanation for the moral crisis that should be confronted with traditional values restoration. Therefore, the human rights agenda is usually narrowed during these times [69].

16 Constitutional Court, Public Hearing held on March 12th of 2019 to follow the decisions of the Ruling T-236 de 2017. More information on https://www.youtube.com/watch?v=zs7CWj_7YX8 (Viewed 18 July 2019). 
During the first semester of 2019, a new cycle or rural politics took place on which the peasants', indigenous and afro-descendants movements mobilized across the country. Such mobilization, called the "Minga," demanded the government to endorse the United Nations Declaration on the Rights of Peasants and Other People Working in Rural Areas, approved in December 2018, and on which the Colombian delegation voted negatively. After formal and informal requirements, President's Duque government reasserted their original position and refused to make public the substantive grounds for such a decision.

- Promotion of corporative agro-extractivism

The reemergence of the right-wing authoritarianism in Colombia is supported by a coalition of different social actors and economic groups. Among such diversity, sectors engaged with deepening and expanding agro-extractivism and natural resources exploitation are having strong representation in the composition of the government. One of the explanations provided by scholars for analyzing the dispute between Santos and Uribe refers to the tension between two different kinds of elites. On the one hand, an entrepreneurial and centralist urban elite engaged with the process of modernization of the country as a means for enabling the environment for capitalist development. On the other hand, an amalgam of regional elites, usually land rentiers, controlling the structures of the state at the regional level and highly reliant on large-scale landed property as a mean for ensuring political and economic power. Although there are crucial controversies between them, there are also agreements. Historically, the urban entrepreneurial elites have less hostile to redistributive agrarian reforms than some regional rural elites. For the first group, the distribution of the access to land represents a minor threat and an opportunity to expand the demand in the rural areas by creating income in those regions; conversely, for some rural elites the enforcement of a redistributive land reform would impact their share of political and economic power directly. However, both actors usually agree on a neoliberal orientation of the economy, the privatization of public services, and other key political economy areas, such as the necessity of expanding the mining and oiling frontier, regardless of the emergence of socioenvironmental conflicts. While Uribe granted mining concessions over more than 8 million hectares from 2002 until 2010, Santos expected the mining sector to be one of the drivers of economic development from 2010 until 2018.

The agrarian problem is the crucial sticking point of the dispute between both elites. Designed and approved during Santos Government, both the land restitution policy and the agrarian chapter of the peace agreement are two landmark policies threatening the current dominant position of some regional rural elites. Arguably, the first indicator of Santos' treason (how the far-right baptized the distance of Uribe's former Minister) was the enactment of the Land Restitution and Victims Law in 2011. Since its first year of enforcement, the far-right has distrusted the land restitution policy. Legal and informal strategies have been enforced for diminishing the impacts of such institutional change. At least in two legislative periods, congresspersons from the Centro Democrático party have attempted to reform the land restitution policy, particularly regarding the bona fide principle. According to this principle, administrative and judiciary authorities must presume the good faith of the victims, while the opponents, meaning the persons owning, using or with the usufruct of the land denounced as dispossessed by the victims, are in the obligation to prove that they acquire such rights following due diligence. The enforcement of such principle affected members of some rural elites that drove the land dispossession process or that bought ownership rights over dispossessed land at low prices because of the depreciation of those actives. Their reaction did not remain at formal channels. In 2016, amidst the appearance of threats against peasants demanding land restitution by so-called "Anti-restitution Armies," the former General Attorney, Alejandro Ordóñez, and the president of Cattle-Ranchers' Federation, José Félix Lafaurie, conducted a public hearing held in one of the most conflictive regions for the enforcement of this policy. They referred to the restitution as 'the first steps towards delivering the territorial control of the country to illegal armed actors' ([70] n.p.). After the victory of the presidential elections of 2018, the former General Attorney was appointed 
as Ambassador to the Organization of American States while the president of the cattle-ranchers' federation was nominated by president Duque as a candidate for General Comptroller, although the Congress finally selected another person. Furthermore, for the direction of the Land Restitution Unit, president Duque appointed a former secretary-general of the oil palm federation. In the Urabá region, one of the most affected by land dispossession, land restitution judges ruled that 25 oil palm companies could not prove due diligence and good faith regarding purchases of ownership rights over the lands currently occupied with oil palm plantations [71]. The cattle-ranchers' federation and the oil palm growers guild are two representative actors that have often opposed against the implementation of the analyzed reforms and that are an essential part of the constituency of the political forces supporting the reemergence of right-wing authoritarianism in Colombia.

The right-wing authoritarian government also jeopardizes the enforcement of the agrarian chapter of the peace agreement. The goal to formalize 7 million and distribute 3 million hectares of land to the landless and nearly landless peasants depends on critical reforms that are not being sufficiently enforced. Conversely, the agrarian agenda of the government encompasses legislative reforms on the agrarian law, that not only impedes the enforcement of the peace agreement but roll-back a key institution in the Colombian agrarian legal framework: the prohibition to grant ownership rights over idle lands or 'baldíos' to subjects that are not considered as agrarian-reform beneficiaries in areas exceeding 450 hectares [62]. This initiative enhances corporative control of the agricultural production by granting agribusiness demands, while discouraging peasant agriculture, opposing what was agreed on the peace accord: an inclusive rural development model for the coexistence of different modes of agricultural production [72].

\section{Conclusions}

The reemergence of right-wing authoritarianism in Colombia could not be understood without considering its relationship with the rise of far-right populists in the Americas, and to a global momentum on which populists are increasingly gaining support amid multiple crises brought, among other causes, by the failure of neoliberal policies. However, the current conditions of the Colombian regime impede consider it as populist, mainly because of lacking massive popular support, particularly compared with the backing towards former president Uribe in the 2000s. As an alternative, the current government is considered in this paper as a case of right-wing authoritarianism.

I consider that human rights-oriented institutional changes in the agrarian field play a crucial role in terms of confronting right-wing authoritarianism, specifically the institutional changes informed by the land restitution policy enacted in 2011 and the peace agreement signed between the Colombian state and the FARC-EP in 2016. Both processes convey alternatives to efficiency as the primary criterion for allocating property rights over rural lands in Colombia. Conversely, they introduced restitution and redistribution criteria for defining who will be entitled with property rights over agricultural lands. In the enforcement of such alternative standards, state actors are obliged to allocate property rights over rural lands to subjects that could not be considered by the mainstream parameters as the most efficient holders. Furthermore, restituting and redistributing property rights over rural lands could affect directly the interest of some regional rural elites highly represented in the constituency of the political project in power. Therefore, the disputes over the enforcement and the prolongation of these reforms are at the core, not only of the current rural politics in Colombia but also in the rearrangement and grouping of political forces confronting or supporting right-wing authoritarianism.

Those institutional changes are critical for addressing current conflicts over land in Colombia. Both frameworks are the result of different process of engagement of different social actors such as peasants', victims', and human rights defenders' movements. By offering alternatives to the mainstream neoliberal paradigm, the enforcement of both frameworks could trigger significant progress towards a democratic distribution of land and progressive access and control of excluded rural poor to land rights. Progressive political forces and social movements engage with those institutional transformations because "broad policy paths can follow from institutional choices" ([30] p.22). For instance, a democratic 
and human rights-based solution for conflicts over land in Colombia can follow from the enforcement of such institutional frameworks. The current disputes over these institutions convey on the one side the defense deployed by social movements of those institutional changes, and on the opposite the efforts of the right-wing authoritarian government for eroding and from preventing them from being enforced.

In the time of populism, the dispute over those institutions is framed in a broader debate over the capacity of the Rule of Law in terms of imposing effective inhibitions of the power of dominant groups and the state [73]. Nor legal reforms nor institutional changes are sufficient for the fulfillment of human rights and the materialization of social justice goals. Disputes over the enforcement of such policies and institutions turn even more sharp in the context of the re-emergence of right-wing authoritarian political projects, that attempt to ignore what social movements and alternative political forces have achieved through the deployment of their political agency.

Whereas significant institutional changes could facilitate the restitution and protection of land rights, and encouraging democratic distribution and access to rural of the excluded rural population, its limits emerge when authoritarian groups reach the control over the state. The evolution of these disputes over institutions between the right-wing government and the social actors engaged with these institutional frameworks is not only a matter of relevant scholar analysis but also a critical step towards the construction of sustainable peace in Colombia.

Funding: This research on which this paper is based is possible thanks to the scholarship granted by "Brot für die Welt" for doing my PhD Research in Social and Political Sciences at the Freie Universität-Berlin (2017-2021). The views and opinions expressed in this article are those of the author and do not reflect the official position of any correspondent institution.

Acknowledgments: This paper is based on my Ph.D. research project, initiated in 2017. I want to thank the guest editors for inviting to write this paper that is based on my dissertation, and that is bringing together multiple reflections developed with scholar-activists across the world gathered at the Emancipatory Rural Politics Initiative (https://www.iss.nl/en/research/hosted-iss/emancipatory-rural-politics-initiative). During the fieldwork conducted in Colombia between December 2018 and April 2019 I discussed with scholars and activists several ideas further developed in this paper. I want to express my gratitude to Alejandro Mantilla, who helped me to frame better some of the notions exposed in this paper, and to Colleen $\mathrm{O}^{\prime}$ Brien for both editing and commenting early versions of this manuscript. I wish to thank the anonymous reviewers, as well as Sthandiwe Yeni, Deniz Pelek and Ricado Jacobs for their valuable comments and for the time and patience they devoted to an early version of this manuscript presented in the JPS Writeshop 2019.

Conflicts of Interest: The author declares no conflict of interest. The funders had no role in the design of the study; in the collection, analyses, or interpretation of data; in the writing of the manuscript, or in the decision to publish the results.

\section{References}

1. Scoones, I.; Edelman, M.; Borras, S.M.; Hall, R.; Wolford, W.; White, B. Emancipatory rural politics: Confronting authoritarian populism. J. Peasant Stud. 2017, 1-20. [CrossRef]

2. Akram-Lodhi, A.H. The Promise? Using and Misusing Authoritarian Populism; International Institute of Social Studies: The Hague, The Netherlands, 2018; p. 10.

3. Borras, S.M. Agrarian social movements: The absurdly difficult but not impossible agenda of defeating right-wing populism and exploring a socialist future. J. Agrar. Chang. 2019. [CrossRef]

4. Alonso-Fradejas, A. Authoritarian corpopulism' supports the rise of sugarcane and oil palm agribusinesses in Guatemala. Available online: https://www.opendemocracy.net/en/authoritarian-corpopulism-supportsrise-of-sugarcane-and-oil-palm-agribusine/ (accessed on 10 November 2018).

5. Berlet, C.; Sunshine, S. Rural rage: The roots of right-wing populism in the United States. J. Peasant Stud. 2019, 46, 480-513. [CrossRef]

6. Jänger, J. The Myth of “Populism". Jacobin Magazine. Available online: https://www.jacobinmag.com/2018/ 01/populism-douglas-hofstadter-donald-trump-democracy (accessed on 15 January 2019).

7. Weyland, K. Clarifying a Contested Concept: Populism in the Study of Latin American Politics. Comp. Politics 2001, 34, 1-22. [CrossRef] 
8. How Human Rights Can Help Challenge Authoritarian Populism; International Institute of Social Studies: The Hague, The Netherlands, 2018.

9. Andrade, D. Populism from above and below: Agriculture and the Political Ambiguities of the Workers' Party in Brazil; Conference paper: Authoritarian Populism and the Rural World; International Institute of Social Studies: The Hague, The Netherlands; Available online: https:/www.tni.org/files/publication-downloads/ erpi_cp_83_andrade.pdf (accessed on 1 July 2019).

10. Morelock, J. Introduction: The Frankfurt School and Authoritarian Populism-A Historical Outline. In Critical Theory and Authoritarian Populism; Morelock, J., Ed.; University of Westminster Press: London, UK, 2018; pp. xiii-xxxviii.

11. Zakrisson, I. Construction of a short version of the Right-Wing Authoritarianism (RWA) scale. Personal. Individ. Differ. 2005, 39, 863-872. [CrossRef]

12. Altemeyer, B. Right-Wing Authoritarianism; University of Manitoba Press: Winnipeg, Canada, 1981.

13. Gounari, P. Authoritarianism, Discourse and Social Media: Trump as the 'American Agitator'. In Critical Theory and Authoritarian Populism; Morelock, J., Ed.; University of Westminster Press: London, UK, 2018; pp. 207-227.

14. Cumbre Agraria. Propuesta política de negociación de la Cumbre Agraria, Campesina, Étnica y Popular, Bogota, Colombia. Available online: https://www.desdeabajo.info/sociedad/item/28932-pliego-paro-31-demayo-de-2016.html (accessed on 10 July 2019).

15. Claeys, P. The Creation of New Rights by the Food Sovereignty Movement: The Challenge of Institutionalizing Subversion. Sociology 2012, 46, 844-860. [CrossRef]

16. Monsalve, S. The Human Rights Framework in Contemporary Agrarian Struggles. J. Peasant Stud. 2013, 40, 239-290.

17. Franco, J.C.; Monsalve, S.; Borras, S.M. Democratic land control and human rights. Curr. Opin. Environ. Sustain. 2015, 15, 66-71. [CrossRef]

18. Franco, J.C. Bound by Law: Filipino-Rural Poor and the Search for Justice in a Plural-Legal Landscape; Governance and political change; Ateneo de Manila University Press: Manila, Philippines, 2011.

19. de Sousa Santos, B.; Rodríguez, C. Law, Politics and the Subaltern in Counter-Hegemonic Globalization. In Law and Globalization from below. Towards a Cosmopolitan Legality; de Sousa Santos, B., Rodríguez, C., Eds.; Cambridge University Press: Cambridge, UK, 2005; pp. 1-26.

20. Tushnet, M. An Essay on Rights. Tex. Law Rev. 1984, 62, 1363-1403.

21. Barreto, J.M. Introduction. Decolonial Strategies and Dialogue in the Human Rights Field. In Human Rights from a Third World Perspective: Critique, History and International Law; Barreto, J.M., Ed.; Cambridge Scholars Publishing: Newcastle upon Tyne, UK, 2013; pp. 1-43.

22. Pensamiento Jurídico. La inconstitucionalidad del Estatuto de Desarrollo Rural Entrevista con el ex magistrado de la Corte Constitucional. In Pensamiento Jurídico; Núm. 25 (2009): Derecho y Política en la era de la Sostenibilidad; Universidad Nacional de Colombia: Bogotá, Colombia, 2009.

23. Ocampo, G.I. Poderes Regionales, Clientelismo y Estado: Etnografías del Poder y la Política en Córdoba, Colombia; Colección Territorio, poder y conflicto; Cinep: Bogotá, Colombia, 2014.

24. Fajardo, D. Para Sembrar la Paz, Hay Que Aflojar la Tierra: Comunidades, Tierras y Territorios en la Construcción de un País; Universidad Nacional de Colombia, Instituto de Estudios Ambientales: Bogotá, Colombia, 2002.

25. Borras, S. Questioning Market-Led Agrarian Reform: Experiences from Brazil, Colombia and South Africa. J. Agrar. Chang. 2003, 3, 367-394. [CrossRef]

26. IGAC. Atlas de la distribución de la propiedad rural en Colombia; IGAC: Bogotá, Colombia, 2012.

27. LeGrand, C. Colonización y Protesta Campesina en Colombia: 1850-1950; Centro Editorial, Universidad Nacional de Colombia: Bogotá, Colombia, 1988.

28. Mondragón, H. Colombia Agrarian Reform - Fake and Genuine. In Promised Land: Competing Visions of Agrarian Reform; Rosset, P., Courville, M., Eds.; Food First Books: Oakland, CA, USA, 2006; pp. 165-174.

29. Berry, R.A. Reflections on injustice, inequality and land conflict in Colombia. Can. J. Lat. Am. Caribb. Stud. 2017, 42, 277-297. [CrossRef]

30. Steinmo, S.; Thelen, K. Historical Institutionalism in Comparative Politics. In Structuring Politics: Historical Institutionalism in Comparative Analysis; Steinmo, S., Thelen, K., Longstreth, F., Eds.; Cambridge University Press: Cambridge, UK, 1992; pp. 1-32.

31. Borras, S.M. Pro-Poor Land Reform; University of Ottawa Press: Ottawa, Canada, 2007. 
32. Thelen, K.; Conran, J. Institutional Change. The Oxford Handbook of Historical Institutionalism. Fioretos, O., Falleti, T.G., Sheingate, A., Eds.; Available online: https://www.oxfordhandbooks.com/view/10.1093/oxfordhb/ 9780199662814.001.0001/oxfordhb-9780199662814-e-3 (accessed on 10 October 2018).

33. Meszaros, G. Taking the Land into Their Hands: The Landless Workers' Movement and the Brazilian State. J. Law Soc. 2000, 27, 517-541. [CrossRef]

34. Houtzager, P.P. The Movement of the Landless (MST), Juridical Field and Legal Change in Brazil. In Law and Globalization from below. Towards a Cosmopolitan Legality; Cambridge University Press: Cambridge, UK, 2005; pp. 218-240.

35. Urrego, R. Cuatro años ocupó al Congreso una ley para las víctimas. Available online: https://www.semana. com/nacion/articulo/cuatro-anos-ocupo-congreso-ley-para-victimas/240317-3 (accessed on 2 October 2018).

36. Saffon, M.P. The Project of Land Restitution in Colombia: An Illustration of the Civilizing Force of Hypocrisy. Estud. Socio-Jurídicos 2010, 12, 109-194.

37. Sánchez, C. Tierra en Transición. Justicia Transicional, Restitución de Tierras y Política Agraria en Colombia; Dejusticia: Bogotá, Colombia, 2017.

38. GMH. Basta Ya! Memorias de Guerra y Dignidad; Imprenta Nacional: Bogotá, Colombia, 2013.

39. Rodríguez, C.; Orduz, N. La consulta previa: Dilemas y Soluciones: Lecciones del Proceso de Construcción del Decreto de Reparación y Restitución de Tierras Para Pueblos Indígenas en Colombia; Documentos (Centro de Estudios de Derecho, Justicia y Sociedad, DeJusticia: Bogotá, Colombia, 2012.

40. McKay, B.M. Democratising land control: Towards rights, reform and restitution in post-conflict Colombia. Can. J. Dev. Stud. Rev. 2017, 39, 163-181. [CrossRef]

41. Amnesty International. A land title is not enough: Ensuring sustainable restitution in Colombia; Amnesty International: London, UK, 2014; p. 71.

42. Gutiérrez-Sanín, F.; Vargas, J. Agrarian elite participation in Colombia's civil war. J. Agrar. Chang. 2017, 17, 739-748. [CrossRef]

43. Moreno, T.; Medina, J.; Fuentes, A.; Lopera, A. Restitución de Tierras en Colombia. Análisis y Estudios de Caso; CINEP: Bogotá, Colombia, 2016.

44. Thomson, F. The Agrarian Question and Violence in Colombia: Conflict and Development. J. Agrar. Chang. 2011, 11, 321-356. [CrossRef]

45. González, F. Poder y Violencia en Colombia; Colección Territorio, Poder y Conflicto; Cinep-Universidad Javeriana: Bogotá, Colombia, 2014.

46. Fajardo, D. Estudio sobre los Orígenes del Conflicto Social Armado, Razones Para su Persistencia y sus Efectos Más Profundos en la Sociedad Colombiana; Contribución al entendimiento del conflicto armado en Colombia. Comisión Histórica del Conflicto y sus Víctimas; Alto Comisionado para la Paz: Bogotá, Colombia, 2015.

47. Molano, A. Fragmentos de la Historia del Conflicto Armado (1920-2010); Contribución al entendimiento del conflicto armado en Colombia. Comisión Histórica del Conflicto y sus Víctimas; Alto Comisionado para la Paz: Bogotá, Colombia, 2015.

48. Pécaut, D. Un Conflicto Armado al Servicio del Statu quo Social y Político; Contribución al entendimiento del conflicto armado en Colombia. Comisión Histórica del Conflicto y sus Víctimas; Alto Comisionado para la Paz: Bogotá, Colombia, 2015.

49. Molano, A. Yo le digo una de las cosas-: La Colonización de la Reserva La Macarena; Fondo FEN Colombia: Bogotá, Colombia, 1988.

50. Molano, A. The Evolution of The Farc: A Guerrilla Group's Long History. NACLA Rep. Am. 2000, 34, $23-31$. [CrossRef]

51. Torrijos, V. Cartografía del Conflicto: Pautas Interpretativas Sobre la Evolución del Conflicto Irregular Colombiano; Contribución al entendimiento del conflicto armado en Colombia. Comisión Histórica del Conflicto y sus Víctimas; Alto Comisionado para la Paz: Bogotá, Colombia, 2015.

52. Vásquez, T. Recursos, política, territorios y conflicto armado. In Una Vieja Guerra en un Nuevo Contexto: Conflicto y Territorio en el sur de Colombia; Colección Territorio, poder y conflicto; Pontificia Universidad Javeriana: Bogotá, Colombia, 2011; pp. 367-428.

53. Ferro, J.G.; Uribe, G. El orden de la Guerra: Las Farc-Ep, Entre la Organización y la Política; Biblioteca personal; CEJA, Centro Editorial Javeriano: Bogotá, Colombia, 2002.

54. Reyes, A. Guerreros y Campesinos: El Despojo de la Tierra en Colombia; Colección Vitral; Grupo Editorial Norma: Bogotá, Colombia, 2009. 
55. Richani, N. Caudillos and the crisis of the Colombian state: Fragmented sovereignty, the war system and the privatisation of counterinsurgency in Colombia. Third World Q. 2007, 28, 403-417. [CrossRef]

56. Salgado, C.; Prada, E. Campesinado y Protesta Social en Colombia, 1980-1995; Cinep: Bogotá, Colombia, 2000.

57. Grajales, J. The rifle and the title: Paramilitary violence, land grab and land control in Colombia. J. Peasant Stud. 2011, 38, 771-792. [CrossRef]

58. Peña-Huertas, R.; Ruiz, L.E.; Parada, M.M.; Zuleta, S.; Álvarez, R. Legal dispossession and civil war in Colombia. J. Agrar. Chang. 2017, 17, 759-769. [CrossRef]

59. LeGrand, C.; Isschot, L.; Riaño-Alcalá, P. Land, justice, and memory: Challenges for peace in Colombia. Can. J. Lat. Am. Caribb. Stud. Rev. 2017, 42, 259-276. [CrossRef]

60. Torres, M.C. La coca Campesina: Un Desafío Para el Posconflicto; Desarrollo y Paz Territorial. Sabemos cómo; Cinep-Red Prodepaz: Bogotá, Colombia, 2016.

61. Gaviria, S.; Mejía, L.F.; Piraquive, G.; Cifuentes, G.; López, R.; Parra, Y. El Dividendo Económico de la Paz en Colombia: Lecciones de la Experiencia Internacional; Departamento Nacional de Planeación: Bogotá, Colombia, 2015; p. 25.

62. Duarte, Carlos La Reforma a la Ley 160 y el complejo de "yo no soy Bran Stark". La Silla Llena—Red Rural. Available online: https:/lasillavacia.com/silla-llena/red-rural/la-reforma-la-ley-160-y-complejo-de-yo-nosoy-bran-stark-71064 (accessed on 3 June 2019).

63. Edelman, M. Sacrifice zones in rural and non-metro USA: Fertile soil for authoritarian populism. Confronting Authoritarian Populism and the Rural World. Available online: https://www.opendemocracy.net/marc-edelman/ sacrifice-zones-in-rural-and-non-metro-usa-fertile-soil-forauthoritarian-populism (accessed on 12 February 2019).

64. Gutiérrez-Sanín, F. El Orangután con Sacoleva: Cien años de Democracia y Represión en Colombia (1910-2010); Debate-IEPRI; Biblioteca IEPRI 25 años: Bogotá, Colombia, 2014.

65. CCJ; IEPRI; Cinep; Somos Defensores. Cuáles Son Los Patrones? Asesinatos de Líderes Sociales en el Post Acuerdo; CCJ_IEPRI-Cinep—Verdad Abierta-Somos Defensores-CCEEUU-Ascamcat-Movimiento Ríos Vivos-Confederación de Acción Comunal: Bogotá, Colombia, 2018; p. 278.

66. Restrepo, A.M.; García, M. “La palabra dicha no vuelve atrás”, Horacio. In Cien Días vistos por Cinep; Cinep: Bogotá, Colombia, 2018; pp. 29-37.

67. Rodríguez-Garavito, C. Ethnicity.gov: Global Governance, Indigenous Peoples, and the Right to Prior Consultation in Social Minefields. Indiana J. Glob. Leg. Stud. 2011, 18, 263-305. [CrossRef]

68. Grajales, J. Land grabbing, legal contention and institutional change in Colombia. J. Peasant Stud. 2015, 42, 541-560. [CrossRef]

69. Alston, P. The Populist Challenge to Human Rights. J. Hum. Rights Pract. 2017, 9, 1-15. [CrossRef]

70. Reyes, A. Fedegán y el procurador contra la restitución de tierras. Razón Pública. Available online: https://www.razonpublica.com/index.php/politica-y-gobierno-temas-27/9414-fedeg\%C3\%A1n-yel-procurador-contra-la-restituci\%C3\%B3n-de-tierras.html (accessed on 10 March 2018).

71. Verdad Abierta. Palma de aceite, la sombra que cubre a nuevo director de la Unidad de Restitución de Tierras. Available online: https://verdadabierta.com/palma-aceite-la-sombra-cubre-nuevo-director-la-unidad-restituciontierras/ (accessed on 30 May 2019).

72. González, F. Los comienzos del gobierno Duque. Realinderamiento ideológico y recomposición del mundo político. In Cien Días vistos por Cinep; Cinep: Bogotá, Colombia, 2018; pp. 5-10.

73. Thompson, E.P. Whigs and Hunters: The Origin of the Black Act; Whigs and Hunters: The Origin of the Black Act; Penguin Books Limited: London, UK, 1975.

(C) 2019 by the author. Licensee MDPI, Basel, Switzerland. This article is an open access article distributed under the terms and conditions of the Creative Commons Attribution (CC BY) license (http://creativecommons.org/licenses/by/4.0/). 